„TURYZM” 1998, t. 8, z. 2

Elżbieta Szkurlat

\title{
NAJSTARSZE OBIEKTY SAKRALNE ŁODZI I ICH WALORY POZNAWCZE
}

\section{LES PLUS VIEUX OBJETS SACRAUX À ŁÓDŹ ET LEURS VALEURS ÉDUCATIVES}

\author{
THE OLDEST SACRED BUILDINGS IN LODZ \\ AND THEIR COGNITIVE VALUE
}

Obiekty sakralne Łodzi są mało dostrzeganym przedmiotem poznania turystycznego naszego miasta. Przez wiele lat dzieje łódzkich kościołów znajdowały się jedynie w kręgu zainteresowań osób duchownych, ograniczających się raczej do opisu powstania i rozwoju pojedynczych parafii. Dopiero od połowy lat osiemdziesiątych obserwować można poważniejsze zainteresowanie tą tematyką oraz opracowania i publikacje historyków, historyków sztuki, architektów. Niniejsze opracowanie jest próbą ukazania walorów poznawczych najstarszych łódzkich obiektów sakralnych w ujęciu chronologicznym wg kolejności ich budowy, w nawiązaniu do rozwoju przestrzennego miasta.

Wartości poznawcze łódzkich kościołów obejmują przede wszystkim historię ich budowy, lokalizację, zróżnicowanie wyznaniowe, architektoniczne. Można je ująć w następujące kategorie:

1. Historia łódzkich kościołów związana jest nierozerwalnie z ważnymi wydarzeniami narodowymi i historią ziem polskich. Na rozwój budownictwa sakralnego Łodzi miało hamujący wpływ powstanie styczniowe oraz popowstaniowe represje władz carskich, wydarzenia rewolucji 1905 r., wybuch I wojny światowej. Polityka zaborców powodowała szereg trudności w budowie kościołów katolickich poprzez wprowadzenie bardzo uciążliwej procedury uzyskiwania zgody na budowę każdej świątyni (w Departamencie Obcych Wyznań w Petersburgu), zatwierdzania planów budowy, kosztorysów i odbioru gotowych obiektów. Władze carskie sprzyjały jednocześnie budownictwu cerkiewnemu w Lodzi. 
2. Historia łódzkich kościołów odzwierciedla dzieje naszego miasta. Śledząc ją dostrzegamy wyraźny związek rozwoju budownictwa sakralnego z rozwojem miasta, okresami pomyślności ekonomicznej Łodzi i jej mieszkańców. Historię tę można podzielić na następujące okresy:

a) od początku XV w., tj. od narodzin miasta, do początku XIX w.: istniała wtedy w Łodzi jedna parafia i jeden kościół katolicki;

b) od $1820^{\mathrm{r}} \mathrm{r}$. do $1920 \mathrm{r}$.: okres intensywnego rozwoju Lodzi i powstania dziewięciu parafii katolickich oraz wielu kościołów innych wyznań;

c) od 1920 r., tj. powstania diecezji łódzkiej i województwa łódzkiego do wybuchu II wojny światowej;

d) okres II wojny światowej;

e) okres powojenny.

3. Budowa i lokalizacja najstarszych kościołów powiązana jest ściśle z rozwojem demograficznym i przestrzennym miasta: powstaniu nowej jednostki osadniczej towarzyszyła budowa świątyni.

4. Poznanie złożonej i zmieniającej się struktury wyznaniowej społeczności Łodzi w XIX i początkach XX w. (tab. I) jest okazją do pouczającego ukazania symbiozy wielonarodowej społeczności naszego miasta w jej różnorodnych powiązaniach społecznych, ekonomicznych, kulturowych oraz godnego uwagi owocnego współdziałania przedstawicieli różnych wyznań.

T a bela I

Struktura wyznaniowa mieszkańców Łodzi w latach 1809-1921

La structure confessionnelle des habitants de Łódź dans années 1809-1921

\begin{tabular}{|c|c|c|c|c|}
\hline \multirow{2}{*}{ Rok } & \multicolumn{4}{|c|}{ Wyznanie (udział w \%) } \\
\cline { 2 - 5 } & katolickie & ewangelickie & mojżeszowe & prawosławne \\
\hline 1809 & 81 & - & 19 & - \\
1820 & 67 & 1 & 32 & - \\
1830 & 58 & 30 & 12 & - \\
1836 & 47 & 44 & 9 & - \\
1840 & 40 & 50 & 10 & - \\
1846 & 51 & 39 & 10 & - \\
1850 & 43 & 43 & 14 & $<1$ \\
1880 & 37 & 39 & 34 & 2 \\
1897 & 48 & 18 & 31 & 2 \\
1911 & 52 & 14 & 32 & $<1$ \\
1918 & 48 & 11 & 40 & $<1$ \\
1921 & 55 & 10 & 34 & \\
\hline
\end{tabular}

${ }^{a}$ Są to wartości przybliżone ze względu na różnice w statystyce wyznaniowej Lodzi w zależności od przyjętego kryterium podziału wyznań, okresu i zasięgu obszaru spisowego.

Ź r ó d ł o: J. J a n c z a k, Struktura spoleczna ludności Łodzi w latach 1820-1918, [w:] P. S a m ús (1997) oraz R. R o s i n (1988). 
5. Walorem architektury sakralnej Łodzi jest odzwierciedlenie w zróżnicowaniu form, usytuowaniu budynku, wystroju - tożsamości wspólnoty wyznaniowej żyjącej w danym czasie i miejscu: parafii, zborze, gminie.

6. Zabytki sztuki sakralnej, ,obmodlone” ołtarze, obrazy, stacje drogi krzyżowej, wytarte klęczniki, kamienne kropielnice i posadzki stanowią cenny, chociaż poznawczo mało doceniany element dziedzictwa kulturowego w naszym mieście świadcząc o duchowych potrzebach kilku pokoleń mieszkańców Łodzi.

Kiedy powstała pierwsza łódzka parafia i pierwszy kościół?

Dokładnej daty nie da się ustalić, brak jest dokumentów. Z pewnością istniała parafia jeszcze przed nadaniem Łodzi praw miejskich, tj. przed rokiem 1423. Świadczy o tym dokument z $1414 \mathrm{r}$. wymieniający opłaty i daniny mieszkańców osady nad Łódką (Ostroga) na rzecz miejscowego księdza ( $\mathrm{R}$ o s i n 1988). Pierwszy kościół wybudowano ok. 1370 r. w najwyżej położonej części osady, na tzw. Górkach Plebańskich, będących lokalnym wyniesieniem, dzielącym dolinę rzeki Łódki i Bałutki - prawdopodobnie na narożniku obecnych ulic Zachodniej i Drewnowskiej. Najstarszy łódzki kościółek nie istnieje. Opisy mówią (Z a n d 1931), że obok drewnianej, krytej gontem świątyni znajdował się mały cmentarz grzebalny, na cmentarzu stała drewniana dzwonnica. W pobliżu był dom plebana, ogród i zabudowania folwarku proboszczowskiego, a także dom parafialny, w którym mieszkał wikary i mieściła się szkoła parafialna. Pierwsza łódzka parafia - pod wezwaniem Wniebowzięcia Najświętszej Maryi Panny - obejmowała nie tylko miasteczko, ale i okoliczne wsie: Zarzew, Widzew, Augustów, Karolew, Koziny. Jest przy tym znamienne, że Lódź, posiadając prawa miejskie, nie pełniła w stosunku do okolicznych wsi ani funkcji ośrodka handlowego, ani wytwórczego, sama posiadała charakter rolniczy i pełniła jedynie funkcję ośrodka parafialnego (K o t e r 1960). Kościół należał do dóbr kościelnych biskupów włocławskich. Sprawozdania z wizytacji kościoła wskazywały, że kościół był bardzo ubogi, zaniedbany, a w połowie XVIII w. w tak złym stanie, że powstała potrzeba rozebrania go i wybudowania nowego. W latach 1765-1968 został wzniesiony nowy modrzewiowy kościółek (M u z n e r o w s k i 1922). W trakcie jego budowy zadecydowano o przeniesieniu cmentarza grzebalnego o 1,5 km na zachód, w rejon obecnej ulicy Ogrodowej. Wybudowany tuż przed I rozbiorem Polski kościółek jeszcze długo był jedynym kościołem Łodzi.

Drugim obiektem sakralnym Łodzi istniejącym w okresie przedprzemysłowym była żydowska bóżnica wybudowana w 1809 r. po utworzeniu w Lodzi gminy żydowskiej. Usytuowano ją przy ul. Dworskiej, późniejszej Wolborskiej (nazywanej też Bożnicza), w pobliżu południowo-wschodniego naroża Rynku Starego Miasta. Była niewielką drewnianą budowlą, obok której postawiono szpital kahalny (S t e fań s k i 1995).

Okresem przełomowym w rozwoju Łodzi był rok 1820, kiedy władze Królestwa Polskiego rozpoczęły politykę protekcyjną dla powstającego przemysłu 
włókienniczego, mianowały Łódź „osadą fabryczną” oraz podjęły decyzję o zlokalizowaniu pierwszej osady sukienniczej początkującej szybki rozwój przemysłu włókienniczego i gwałtowny rozwój miasta. Rozwój przemysłowy i ludnościowy miasta nie szedł jednak $w$ parze $z$ erygowaniem nowych parafii i kościołów katolickich. Przyczynami głównymi było to, że:

1. Zaborcy nie sprzyjali budowie kościołów katolickich.

2. Władze wydając szereg dekretów regulujących osadnictwo, objęły szczególną protekcją osadników spoza granic Królestwa Polskiego, mogących zapewnić wysoko kwalifikowaną siłę roboczą. Znaczna więc część osadników przybywających do Łodzi i bogacących się najszybciej była innych wyznań: ewangelicko-augsburskiego, mojżeszowego, prawosławnego.

Względy powyższe sprawiły, że drugim wybudowanym w Lodzi kościołem był kościół ewangelicki. Już w dokumencie z 1820 r. rząd zapewnił imigrantom niemieckim możliwość wybudowania w nowej osadzie kościoła ewangelickiego i domu dla pastora. Starania o utworzenie w Łodzi parafii ewangelicko-augsburskiej rozpoczęli jeszcze wcześniej imigranci z ziem niemieckich, osiedleni w okolicznych wsiach, m.in. Nowosolnej, Mileszek, Augustowa, Bedonia. W kilka lat później wybudowano na Rynku Nowego Miasta (obecnie pl. Wolności) świątynię dla protestantów p.w. Świętej Trójcy. Był to pierwszy murowany kościół na terenie miasta (S t e f a ń s k i 1995). Klasycystyczna architektura i rozmiary kościola pięknie komponowały się z nowomiejskim ratuszem. Wielkość i rozwój parafii Świętej Trójcy odpowiadały dynamice przemysłu i miasta oraz przyrostowi liczebnemu narodowości niemieckiej: w latach trzydziestych XIX w. protestanci stanowili ok. 30\% ludności miasta, w roku 1838 już ok. $40 \%$, a w połowie XIX w. blisko $50 \%$. Oddany do użytku w 1829 r. kościół Św. Trójcy był wykonany mało solidnie, toteż w następnych latach był wielokrotnie naprawiany i remontowany.

W budowie obiektów sakralnych Łodzi daje się zauważyć pewną prawidłowość w czasowym i przestrzennym rozlokowaniu kościołów katolickich i protestanckich: budowaniu świątyń katolickich towarzyszy rozbudowa lub budowa kościołów protestanckich. Kiedy rozpoczęto budowę kościoła katolickiego na Starym Mieście, fabrykanci niemieccy rozpoczęli przebudowę kościoła na Nowym Rynku (lata 1889-1892). Przebudowana od podstaw świątynia ewangelicka wzniesiona została w stylu eklektycznym, z przewagą cech neorenesansowych z elementami romańskimi. Na solidnej, ciężkiej konstrukcji górnych sklepień wsparto ogromną kopułę górującą nad całością, nie odpowiadającą już proporcjami dawnej, pięknej architektonicznej kompozycji kościoła i ratusza. Po II wojnie światowej kościół został przemianowany na kościół garnizonowy Wojska Polskiego. Po poświęceniu nadano mu wezwanie Zesłania Ducha Świętego, a w roku 1948 erygowano przy nim parafię.

Drugą świątynią i parafią katolicką Łodzi był kościół i parafia p.w. Podwyższenia Świętego Krzyża (G r a l i ń s k i 1948). Potrzeba budowy drugiego 
kościoła związana była głównie z powstaniem osady sukienniczej Nowe Miasto, tworzeniem się kolonii tkaczy bawełniano-Inianych wzdłuż ul. Piotrkowskiej i kolonii prządków Inu wzdłuż ul. Widzewskiej (Kilińskiego). Zabiegi o budowę drugiego kościoła katolickiego rozpoczął proboszcz parafii Wniebowzięcia Najświętszej Maryi Panny, ks. Wojciech Jakubowicz. Zezwolenie na budowę kościoła uzyskał dopiero w roku 1860. Zaraz rozpoczęto jego budowę u zbiegu ulic Dzikiej (Sienkiewicza) i Przejazd (Tuwima). Nowy budujący się kościół otrzymał wezwanie św. Jakuba. Budowa została wstrzymana wraz z wybuchem powstania styczniowego. Ks. proboszcz Jakubowicz został aresztowany i zesłany na Syberię za sprzyjanie powstańcom. Dopiero po ośmiu latach udało się wznowić budowę kościoła i w 1875 r. część świątyni została poświęcona i przekazana do użytku wiernych jako kościół filialny parafii Wniebowzięcia NMP. Kościół wybudowany jest w stylu neoromańskim - charakteryzującym się wyraźną czytelnością konstrukcji - na planie krzyża, z wieżą od frontu i niewielkimi oknami. W oltarzu głównym znajdują się relikwie św. Justyna i św. Agnieszki. Wnętrze kościoła zdobią bogate ołtarze, konfesjonały, stacje Drogi Krzyżowej. Znaczne ofiary na rzecz budowy kościoła pochodziły od łódzkich fabrykantów, Karola Scheiblera i Edwarda Herbsta: fundowali oni ołtarze, ambonę, organy. W 1880 r. ukończono budowę wieży kościoła i ustawiono na niej miedziany, złocony krzyż o wysokości $6 \mathrm{~m}$. Parafii odrębnej jednak nie było, dopiero w 1885 r. udało się uzyskać zgodę na jej erygowanie. Parafia p.w. Podwyższenia Świętego Krzyża objęła całą południową część miasta (od pl. Wolności) i wsie: Augustów, Rokicie, Widzew, Zarzew. Z historią tego kościoła wiążą się zarówno dawne, jak i całkiem nam bliskie wydarzenia świadczące o nierozerwalności potrzeb duchowych, religijnych, z potrzebą tożsamości narodowej. W roku 1904 zgromadzeni na nabożeństwie wierni zaczęli śpiewać pieśń Boże, coś Polskę... Przed kościołem wkrótce pojawili się Kozacy. Gubernator przebywający w Lodzi polecił kościół zamknąć, wypuścić tylko kobiety i dzieci. Od strony ulicy Sienkiewicza zgromadzili się protestujący mieszkańcy Łodzi. Doszło do rozlewu krwi... Podczas II wojny światowej kościół był przeznaczony dla niemieckich katolików.

W czasie gdy powstawała druga parafia katolicka w Łodzi, również z ewangelickiej parafii Świętej Trójcy została wydzielona druga parafia i rozpoczęto na jej potrzeby budowę zboru ewangelicko-augsburskiego św. Jana Ewangelisty. Murowaną z cegły, neogotycką świątynię usytuowano w pobliżu kościoła p.w. Podwyższenia Świętego Krzyża - również przy ul. Dzikiej (obecnie Sienkiewicza 60). W roku 1945 otrzymali go księża jezuici. Do czasu erekcji parafii w 1950 r. był on kościołem filialnym parafii Podwyższenia Świętego Krzyża. Aktualnie mieści się w nim ośrodek duszpasterstwa księży jezuitów i siedziba parafii Najświętszego Serca Jezusowego.

Wzrost liczby wiernych w najstarszej parafii łódzkiej (Wniebowzięcia NMP) - głównie w wyniku rozwoju od połowy XIX w. zakładów bawełnianych Poznań- 
skiego - sprawił, że niewielki modrzewiowy kościółek na pl. Kościelnym nie mógł sprostać potrzebom parafii. Dlatego też w roku 1888 rozpoczęto budowę na pl. Kościelnym nowego kościoła, a stary, drewniany, przeniesiono na cmentarz parafialny przy ulicy Ogrodowej. Po przeniesieniu na cmentarz osadzono go na fundamencie z cegły oraz oszalowano wewnątrz i zewnątrz. Dach pierwotnie kryty gontem przykryto papa. Kościół ten miał służyć wiernym tylko do czasu wybudowania nowej świątyni. Według zarządzenia władz carskich miał być rozebrany zaraz po jej wybudowaniu. Jednakże przed ukończeniem budowy nowego kościoła członkowie dozoru parafialnego przesłali do Petersburga petycję $\mathrm{z}$ prośbą o zezwolenie na umieszczenie w wyznaczonym do rozbiórki kościele obrazu św. Mikołaja, dla upamiętnienia cudownego uratowania następcy tronu w czasie jego podróży do Japonii. Po tym taktycznym posunięciu władze carskie zgodziły się na pozostawienie starego kościoła - otrzymał wezwanie św. Józefa i był kościołem filialnym parafii Wniebowzięcia NMP. W roku 1909 erygowana została przy nim samodzielna parafia. Świątynię ponownie wyremontowano, rozbudowano, położono posadzkę, odnowiono ołtarze. Kościółek ten jest jedynym zabytkiem z okresu Łodzi rolniczej.

Na miejscu modrzewiowego kościółka na pl. Kościelnym wybudowany został w latach 1888-1897 monumentalny, neogotycki kościół z ofiar złożonych przez mieszkańców Łodzi. Kościół budowali głównie robotnicy z fabryki Poznańskiego. O ich poświęceniu przy budowie kościoła świadczy fakt, że pracując po kilkanaście godzin dziennie przy krosnach, kościół budowali również w nocy. Obecny kościół wybudowany wg projektu K. Wojciechowskiego, jest budowlą w stylu neogotyckim, tzw. „wiślano-bałtyckim”, trzynawowy na planie krzyża łacińskiego, na ścianach zewnętrznych z systemem szkarp (przypór) i wnęk, u góry zwieńczony ażurową balustradą i sterczynami (iglicami). Nad całością dominują dwie wieże. Trzy wejścia obwiedzione są ostrołukowymi portalami, wnętrze nakrywają sklepienia krzyżowo-żebrowe. W kościele znajduje się piękny ołtarz: tryptyk przedstawiający sceny Wniebowzięcia NMP. W bocznym, drewnianym neogotyckim ołtarzu usytuowany jest obraz Matki Boskiej Łódzkiej (nazywany też obrazem Matki Boskiej Bolesnej, Matki Boskiej Łaskawej) słynący licznymi łaskami i otoczony kultem. Badania wstępne obrazu pozwalaja przyjąć, że jest to najstarszy łódzki obraz, pochodzący z początku XVII w. (U z n a ń s k i 1990). Wyposażenie kościoła bardzo ucierpiało w okresie II wojny światowej. Niemcy najpierw kościół ograbili, a później zamienili na magazyn wojskowy oraz skład pierza i mebli.

Zmieniająca się w XIX w. struktura narodowa i wyznaniowa mieszkańców Łodzi sprawiła, że rosła potrzeba budowy świątyń innych wyznań: mojżeszowego i prawosławnego.

Napływ ludności żydowskiej do Łodzi wiąże się z początkiem XIX w. i rozwojem przemysłowym miasta. W 1820 r. gmina żydowska liczyła 259 osób, co stanowiło $1 / 3$ część ludności Łodzi. W następnych latach udział procentowy 
ludności wyznania mojżeszowego zmniejszył się, lecz liczba bezwzględna Żydów rosła. Do roku 1862 przybywająca do Łodzi ludność żydowska musiała osiedlać się w wyznaczonym rewirze. Obejmowal on wschodnią część Starego Miasta. Istniejąca od $1809 \mathrm{r}$. drewniana bożnica była obiektem bardzo niewielkim, toteż w pierwszej połowie XIX w. zaczęły powstawać, na terenie rewiru żydowskiego, liczne prywatne domy modlitwy (S t e f a ń s k i 1995). W roku 1860 rozpoczęto budowę na placu przy ul. Wolborskiej nowej, murowanej bożnicy. Budowa trwała długo i została zakończona dopiero w 1871 r. Architektura budynku nawiązywała bardzo wyraźnie do form orientalnych określanych mianem „stylu mauretańskiego”, wprowadzonych wcześniej przez Henryka Marconiego w bożnicach w Łomży i Włocławku. Cechy bizantyjskie architektury synagogi przy ul. Wolborskiej zostały jeszcze mocniej uwypuklone podczas przebudowy i renowacji obiektu w latach 1897-1914. Zniesienie w 1862 r. rewiru żydowskiego spowodowało gwałtowne przenoszenie się Żydów poza obręb dawnego rewiru oraz podjęcie przez tzw. ,postępowych” Żydów z najzamożniejszym żydowskim przedsiębiorcą łódzkim, Izraelem Kalmanowiczem Poznańskim, starań o budowę nowej synagogi. Budowę jej rozpoczęto w $1881 \mathrm{r}$. na placu położonym u zbiegu ulic Zielonej i Spacerowej (obecnie al. T. Kościuszki), a zakończono w 1887 r. W architekturze „postępowej” synagogi dominowały formy chrześcijańskie - romańskie i neorenesansowe, w mniejszym stopniu bizantyjskie - głównie w bogatym wystroju wnętrza. Mniejsze znaczenie miały synagogi: wybudowana w latach 1899-1904 synagoga przy ul. Wólczańskiej 6, synagoga przy ul. Zachodniej 56 i Południowej 28.

W dawnej dzielnicy żydowskiej hitlerowcy utworzyli w lutym 1940 r. pierwsze na ziemiach polskich getto dla ludności żydowskiej: ok. 200000 Żydów łódzkich zamknięto za drutami kolczastymi. Uratowała się tylko garstka, ok. 1 tys. ludzi. W czasie eksterminacji ludności żydowskiej zniszczono także zabytki kultu religijnego, w tym piękną mauretańską synagogę u wylotu ulicy Wolborskiej. Hitlerowcy zniszczyli też wspaniałą synagogę przy ul. Spacerowej oraz synagogi przy ul. Wólczańskiej i Zachodniej.

Znaczniejszy napływ prawosławnych do Lodzi (tab. I) nastapił po upadku powstania styczniowego i był konsekwencją polityki rusyfikacyjnej zaborcy rosyjskiego. Pierwszą łódzką świątynią prawosławną jest piękna cerkiew św. Aleksandra Newskiego, wybudowana wg projektu naczelnego architekta Łodzi, Hilarego Majewskiego, w 1884 r. przy ul. Widzewskiej (Kilińskiego). Wyróżnia się ona spośród innych cerkwi wznoszonych na ziemiach polskich w II połowie XIX w.: Majewski oparł się wiernie na tradycji architektonicznej obrządku wschodniego i wzorcach bizantyjskich. W późniejszym czasie wybudowano jeszcze dwie inne świątynie prawosławne: cerkiew garnizonową św. Aleksego (przy ul. Jerzego) oraz św. Olgi (przy ul. Piramowicza). Świątynia przy ul. Jerzego została w 1918 r. zamieniona na katolicki kościół garnizonowy, a od roku 1945 spełnia funkcję kościoła filialnego parafii św. Józefa. 
Rozbudowa miasta głównie w rejonie tzw. posiadeł wodno-fabrycznych nad rzeką Jasień, oraz powstanie osady tkaczy wzdłuż ulicy Piotrkowskiej łączącej posiadła z Nowym i Starym Miastem sprawiły, że kościół p.w. Podwyższenia Świętego Krzyża i parafia - licząca pod koniec XIX w. ponad 100 tys. parafian - nie mogły zaspokoić potrzeb duchowych katolickich mieszkańców Łodzi. W 1890 r. proboszcz parafii p.w. Podwyższenia Świętego Krzyża podjął inicjatywę i starania o uzyskanie placu pod budowę nowej świątyni. Wkrótce wyznaczono plac przed Szpitalem św. Aleksandra (obecnie Seminarium Duchowne) na tzw. Słomianym Rynku (G r a l i ń s k i 1949). Miejsce zostało niezbyt fortunnie dobrane: teren był podmokły, zabagniony, grunt nie wytrzymywał obciążenia i pojawiły się później trudności przy budowie i konserwacji kościoła. Ogłoszono konkurs na projekt architektoniczny, a w 1900 r. przystapiono już do prac budowlanych. W $1901 \mathrm{r}$. poświęcony został plac i kamień węgielny. W latach 1902-1907 wzniesione zostały mury kościoła i wieża do wysokości dachu. W 1907 r. urządzono po prawej stronie nawy kaplicę, poświęcono ją i sprawowana była Msza Św. przez księży z parafii Podwyższenia Świętego Krzyża. W grudniu 1909 r. została erygowana przy budującym się kościele parafia p.w. św. Stanisława Kostki. Pierwszym proboszczem został ks. Stanisław Tymieniecki. Budowę kościoła ukończono i kościół został poświęcony w roku 1912. Po erygowaniu w 1920 r. diecezji łódzkiej, kościół został podniesiony do godności Katedry, a dotychezasowy proboszcz został pierwszym ordynariuszem diecezji. Po ukończeniu budowy murów i przykryciu w 1910 r. przystąpiono do upiększania świątyni: zainstalowano piękne, figuralne witraże sprowadzone z Saksonii, zainstalowano elektryczność. Główny ołtarz neogotycki ufundował Juliusz Heinzel - prezes Komitetu Budowy Kościoła, ołtarze boczne ufundowali kupcy i robotnicy fabryki L. Geyera, zakupiono piękną gotycką ambonę, położono posadzkę, przystapiono do montażu organów. Ciekawa jest historia fundacji, odlewania i dzieje dzwonu świątyni. Myśl fundacji dzwonu i fundusze dali rzemieślnicy łódzcy. Uroczyste odlewanie, chrzest dzwonu odbyły się w 1911 r. Dano mu na imię Zygmunt. Przetrwał I wojnę światowa, jednak w 1943 r. Niemcy zabrali go i użyli na cele wojenne. W okresie międzywojennym wybudowano wieżę, przykryto kościół miedzianą blachą, w podziemiach wybudowano kryptę, wzmocniono mury, odwodniono teren. Tragiczny był los katedry w okresie II wojny światowej, tak tragiczny jak dzieje Polski, mieszkańców Łodzi, księży. W roku 1941 gestapo ograbiło katedrę i zamieniło na skład wojskowy; ciężkim uszkodzeniom uległa architektura wnętrza: połamane ołtarze, wybite witraże, powstały zacieki, odpadały tynki. W podziemiach katedry Niemcy urządzili pieczarkarnię. Po wojnie przystappiono do usuwania zniszczeń oraz remontu i przyozdobienia katedry. Tragicznym powojennym wydarzeniem był jej pożar w maju 1971 r.; zniszczył on dach, organy oraz wnętrze katedry. Zagrażające niebezpieczeństwo zmusiło do zamknięcia kościoła. Otwarto go dopiero w grudniu $1972 \mathrm{r}$. 
Na początku XX w. w dalszym ciągu znaczny odsetek ludności Łodzi stanowili protestanci (tab. I). Liczba protestantów zmniejszyła się dopiero pod koniec dwudziestolecia międzywojennego, ale jeszcze w 1928 r. erygowano nową parafię ewangelicko-augsburską przy wybudowanym w pobliżu łódzkiej katedry, kościele św. Mateusza. Budowa kościoła została rozpoczęta w 1909 r. Szczególnym osiagnięciem budowlanym było wykonanie centralnej części kościoła w formie żelbetowej kopuły o średnicy $26 \mathrm{~m}$. Prace nad budową przerwał wybuch I wojny światowej. Zakończenie budowy kościoła i oddanie go do użytku wiernych nastapiło dopiero w 1928 roku. Kościół św. Mateusza jest budowlą centralną w stylu neoromańskim, zwieńczoną $80 \mathrm{~m}$ wieżą z wysokim iglicowym hełmem, ozdobioną dekoracyjnym portalem i rozetami. Konkuruje swymi rozmiarami i bogatym wystrojem wnętrza z większą, i o lżejszej konstrukcji, bryłą znajdującej się w pobliżu katedry katolickiej.

W 1900 r. pojawily się plany budowy nowego kościoła na terenie przedmieścia Łodzi - Zarzewa. Z inicjatywy tamtejszego właściciela młyna i cegielni - Józefa Meisnera, który ofiarował plac pod budowę położony pomiędzy ulicami Zarzewską i Skierniewicką oraz przy wsparciu finansowym Edwarda Herbsta (zięcia Scheiblera), został wybudowany i oddany do użytku w $1905 \mathrm{r}$. kościół katolicki pod wezwaniem św. Anny. Wezwanie kościoła związane jest z darem rodziny Herbstów, którzy w ten sposób pragnęli uczcić pamięć zmarłej w wieku 9 lat córki Anny Marii. Służyć miał głównie robotnikom zakładów Scheiblera, mieszkającym w osiedlach robotniczych przy Wodnym Rynku, Przędzalnianej, Księżym Młynie oraz mieszkańcom osady tkackiej Szlezyng. Utworzona przy kościele parafia obejmowała również część Widzewa. Architektura kościoła nawiązuje do motywów neoromańskich i przełamuje dominację form neogotyckich w architekturze sakralnej Łodzi przełomu XIX i XX w.

Mimo erygowania na terenie Łodzi w 1909 r. trzech nowych parafii potrzeby duszpasterskie łodzian nie mogły być zaspokojone. Intensywny rozwój na początku XX w. wielkiego prywatnego osiedla robotniczego związanego z fabryką Heinzla i Kunitzera (Widzewska Manufaktura) oraz stosunkowo duża odległość do kościoła Podwyższenia Świętego Krzyża sprawiły, że zaistniała potrzeba budowy kościoła na Widzewie. Mieszkańcy Widzewa zaczęli starać się o budowę kościoła i zabiegać u Kunitzera o pomoc w tej sprawie (S t a ń c z a k 1929). Kunitzer, chociaż sam był ewangelikiem, odniósł się do spraw budowy kościoła dla katolików bardzo życzliwie: ofiarował on zakupiony w parku helenowskim pawilon wystawowy oraz plac pod jego ustawienie przy ul. Niciarnianej. Proboszcz parafii p.w. Podwyższenia Świętego Krzyża pomógł wyposażyć go w oltarz, ambonę i w 1902 r. poświęcił jako kościół filialny pod wezwaniem Niepokalanego Poczęcia Najświętszej Maryi Panny. Po usilnych staraniach mieszkańców Widzewa - za zgodą władz rosyjskich - została utworzona przy nim w 1911 r. osobna parafia. Patronem parafii obrany został św. Kazimierz Królewicz. Kościół obecny wybudowany został w latach 1925-1936. Jako jeden 
z trzech czynny był w okresie okupacji. W głównym ołtarzu umieszczone są relikwie św. Kazimierza Królewicza sprowadzone z Wilna przez biskupa Tymienieckiego do katedry łódzkiej, a w 1929 roku uroczyście wprowadzone do kościoła p.w. św. Kazimierza.

Pod koniec XIX w. budowę nowego kościoła podjęli mieszkańcy przedmieścia Łodzi Chojny Stare, gdzie znajdował się drewniany kościólek wybudowany w 1493 r. jako kościół filialny parafii w Mileszkach. Erygowanie przy nim w 1892 r. odrębnej parafii św. Wojciecha wiąże się z rozwojem przestrzennym Łodzi, rozwojem przemysłu dającym zatrudnienie przybywającym do „Ziemi Obiecanej" i osiedlającym się na przedmieściach robotnikom. Obecny kościół p.w. św. Wojciecha budowany był w latach 1902-1924 z przerwą spowodowaną I wojną światową. W kościele znajdują się zabytki sztuki: krzyż i kielich barokowy z XVIII w., stacje Drogi Krzyżowej z XVIII w., obraz Matki Boskiej Pocieszenia zwany obrazem Matki Boskiej Chojeńskiej, monstrancja z XVII w., na bramie przykościelnego cmentarza kula z wieży dawnego, drewnianego kościółka z $1643 \mathrm{r}$.

W roku 1905 proboszcz parafii św. Wojciecha wystawił kaplicę w miejscu obecnego kościoła p.w. Przemienienia Pańskiego jako pomocniczą. W latach 1923-1925 dobudowano do niej trzynawowy kościół. Ponieważ była to budowla bez żadnego stylu, przebudowano ją w następnych latach wg projektu inż. arch. Wiesława Lisowskiego.

Najbardziej na północ wysuniętą częścią Łodzi był Julianów, dołączony do terytorium miasta w $1915 \mathrm{r}$. Tereny Julianowa należały do parafii Wniebowzięcia NMP. Ze względu na dużą odległość od kościoła już w roku 1912 zaczęto czynić starania o wzniesienie kościoła na Julianowie. Historia jego jest podobna do historii budowy kościoła p.w. św. Kazimierza. Lódzki fabrykant, Juliusz Heinzel, ofiarował plac pod budowę świątyni, mieszkańcy wystarali się o prowizoryczny budynek drewniany (po wystawie przemysłowej w parku helenowskim) i w 1914 r. została oddana do użytku prowizoryczna kaplica. Była ona podstawą do erygowania w 1915 r. parafii p.w. Najświętszego Serca Jezusowego. Kościół obecny wybudowany został po II wojnie światowej.

W 1920 r. utworzona została diecezja łódzka. Utworzenie jej nastąiło w przełomowym dla historii Polski i Łodzi momencie. Początkuje ono też nowy etap dziejów łódzkiego budownictwa sakralnego, którego historia wykracza poza ramy tematyczne niniejszego opracowania.

\section{PIŚMIENNICTWO}

B u d z i a r e k M., 1988, Lódź wielowyznaniowa - cz. I, Biuletyn ZW PTTK w Lodzi „Wędrownik" nr III.

B u d z i a r e k M., 1988, Lódź wielowyznaniowa - cz. II, Prawostawie, Biuletyn ZW PTTK w Lodzi „Wędrownik” nr IV. 
B u d z i a r e k M., 1989, Łódź wielowyznaniowa-Protestantyzm, Biuletyn ZW PTTK w Łodzi "Wędrownik" nr II-III.

Diecezja Lódzka. Terytorium. Organizacja. Duchowieństwo, 1987, Diecezjalne Wyd. Lódzkie.

G r a 1 i ń s k i T., 1948, Dzieje powstania drugiego kościola Lodzi, „Wiadomości Diecezjalne Łódzkie", R. 22, nr 3.

G r a 1 i ń s k i T., 1949, Kościót katedralny św. Stanistawa Kostki w Lodzi, „Wiadomości Diecezjalne Łódzkie", R. 22, nr 12, 1948; R. 23, nr 1 i 2.

G r a l i ń s k i T., 1951, Erekcje parafii diecezji lódzkiej, „Wiadomości Diecezjalne Łódzkie”, R. $25, \mathrm{nr} 7$.

G r a l i ńs k i T., 1952, Spis parafii i kościolów diecezji tódzkiej i krótki ich opis historyczny, „Wiadomości Diecezjalne Łódzkie”, R. 23, nr 10.

G r a $l$ i ń s $k$ i T, 1954, Kronika historyczna diecezji tódzkiej, „Wiadomości Diecezjalne Lódzkie", R. 28, nr 4-9.

K o t e r M., 1960, Geneza ukladu przestrzennego Lodzi przemystowej, PWN.

M u z n e r o w s k i S., 1922, Przyczynki do monografii Łodzi, Łódź.

R o s i n R. (red.), 1988, tódź. Dzieje miasta, PWN, Łódź.

S a m ús P., 1997, Polacy - Niemcy - Żydzi w Lodzi $w$ XIX - XX w., Instytut Historii UŁ, Łódź.

S t a ń c z a k Sz., 1929, Przewodnik rzymsko-katolickiej parafii św. Kazimierza, Nakładem rz-k. parafii św. Kazimierza, Łódź.

$\mathrm{S}$ t e f a ń s k i K., 1995, Architektura sakralna Lodzi w okresie przemystowego rozwoju miasta 1821-1914, Wyd. Ut, Łódź.

S z k u r ł a t E., 1991, Najstarsze kościoly Lodzi, PTTK - Regionalna Pracownia Krajoznawcza w Lodzi.

U z n a ń s k i P., 1990, Obraz Matki Boskiej Łódzkiej. Badania wstępne, „Miscelanea Lódzkie” 1(9).

W a c h o w s k a B., 1976, Struktura wyznaniowo-narodowościowa i spoleczno-zawodowa proletariatu tódzkiego (1918-1929), „,Rocznik Łódzki”, t. XXI.

$\mathrm{Z}$ a n d A., 1931, Lódź rolnicza 1332-1793. Studium historyczne o topografii, stanie gospodarczym, organizacji prawnej i kulturze Lodzi, ,Rocznik Łódzki”, t. 2.

Z i ó 1 k o w s k a A., 1987, Diecezja tódzka i jej biskupi w świetle dokumentów, Lódź.

Dr Elżbieta Szkurłat

Pracownia Dydaktyki Geografii

Uniwersytet Łódzki

al. Kościuszki 21

90-418 Łódź
Wplynęło:

9 września $1998 \mathrm{r}$. 